\title{
Historical palaces and gardens in Ukraine and problems of their revalorization
}

\author{
Oresta Remeshylo-Rybchynska \\ Institute of Architecture, Lviv Polytechnic National University
}

In Ukraine the problem of protection of cultural heritage especially palaces and gardens and their revalorization is exceptionally actual and is in process of effective model's research as a component of cultural politics.

For better understanding of the problem, it's necessary to look through specialties of Ukrainian territory and localization of historical palaces and gardens; try to classify historical palaces and gardens; illuminate of specifics that revalorization of historical palaces and gardens monuments artwork has; develop of a new vision for solving the revalorization of historical palaces and gardens as cultural landmarks of Ukraine.

Today in Ukraine the so-called French model of organizational politics dominates for protection cultural heritage, according to which the total control of the state over fund raising and distributing is accepted [1].

According to the Constitution of Ukraine State law protects the cultural heritage. For realization of constitution principles in two years of independence several laws had been created, among those the law "About protection of cultural heritage" (2000). The Ministry Cabinet of Ukraine signed a few documents, some of them the list of historical heritage places, protected by special state law. As to historical palaces and gardens they are important components of cultural heritage that has a big potential in terms of curing people, creating the atmosphere of contempt of their emotional and esthetical feeling, active perception of nature and art works. Palaces and gardens also are necessary component of architectural and art filling of cities and towns of Ukraine, big part of forming their artistic image, important piece in spatial composition, and deserve big funding reserve from local and state budgets.

As one of the biggest European states, Ukraine occupies the area of 603,7 thousand $\mathrm{m}^{2}$, for analogy - French Republic -544 thousand $\mathrm{m}^{2}$, Republic of Poland $-312,7$ thousand $\mathrm{m}^{2}[2]$.

The evaluation of territory, in terms of program plans of society development and appropriate norms (social, industrial, urban planning, ecological and others), there is a suggestion to insert, using the integral model of planning territory organization of Ukraine. The use of this model in urban planning and projecting on the state level counts existing monuments of garden and park art in different regions of state in general. The important constructional factors are main planning axis and plan centers that form the basic skeleton of territory regions and are main fields of attraction potential investments. 
On the regional level the main purpose of urban planning documentary in organizing territories is a construction of generalizing model of plan organization of the specific region [3]. This mentions the situation and spatial connection of the main elements of territory system. In terms of this model the process of searching and accounting of the monuments of historical palaces and gardens architecture has to take place and on this basis managing the project of region development.

Also one of the most important factors in process of concentration of efforts around separate territories development is an activating of multifunctional territories use on both sides of the state border of neighbouring countries that form Transborder zones. One of the perspective ways of development of Trans-border regions is protection and sanitation of environment, forming the system of recreational, healthy and tourist centers and districts, protection of historical palaces and gardens landmarks and common projects on their revalorization. Therefore, for example, according to the object of two side projecting, meaning Ukrainian-Polish region, several international activities had been made for the past few years, initiated the collaboration on the domain of politics and protection of cultural landscapes [4].

On the Ukrainian territory the great amount of historical and cultural heritage is concentrated, including urban, forming valuable environment that has historical, ethnical, national, esthetical specialties, traditions in building environment and planning, landscape organization of territories. Objects of garden and park art are included in the list of urban planning monument, architecture and landscape. Big recourse of cultural landscapes in Ukraine is important not only for Ukrainian but for Polish, Jewish, Austrian, Russian, German, Tatar and other cultures and demand collaboration in their protection.

Nowadays our country counts 1399 cities and towns and approximately 8 thousands of villages that have historical and cultural value [5], 46 historical cultural and architectural parks, 6 of which are national [6]. Ukraine has a lot of significant parks and gardens, 83 landmarks of park and garden art are accounted and protected by state and have a national status and 427 parks - local landscape status [7]. Among them well known palace and garden complexes in Kachanivka, Nemyriv, Sorochynci, Tulchyn, Pidhirci, city palaces in Lviv, Crimea palaces and others (Pictures 1-12).

These historical palaces and gardens are the part of the complex green zone territory, which is an important element of the planning structure of the settlement. They also are represented by classification of green territories of Ukraine.

In the same time, Historical palaces and gardens are the places, where the history, culture, and the level of civilization of the people is shown. There not only material but aesthetic values of $t$ mankind are reflected Specially Historical palaces and gardens are the best examples where the art synthesis is illustrated.

The territory of gardens and parks landmark has its zones according to the demand of botanic gardens; on this space the excursions and recreation could take place, the plants are being taken care of (sanitary chop and reconstruction chop), the architecture and landscape environment is conserved [8].

According to the existing classification, monuments of palaces and garden art belong to artificially created zones. They are characterized by different categories of natural reserve fond and also by certain tasks of protection and renovation of natural resources [9]. 


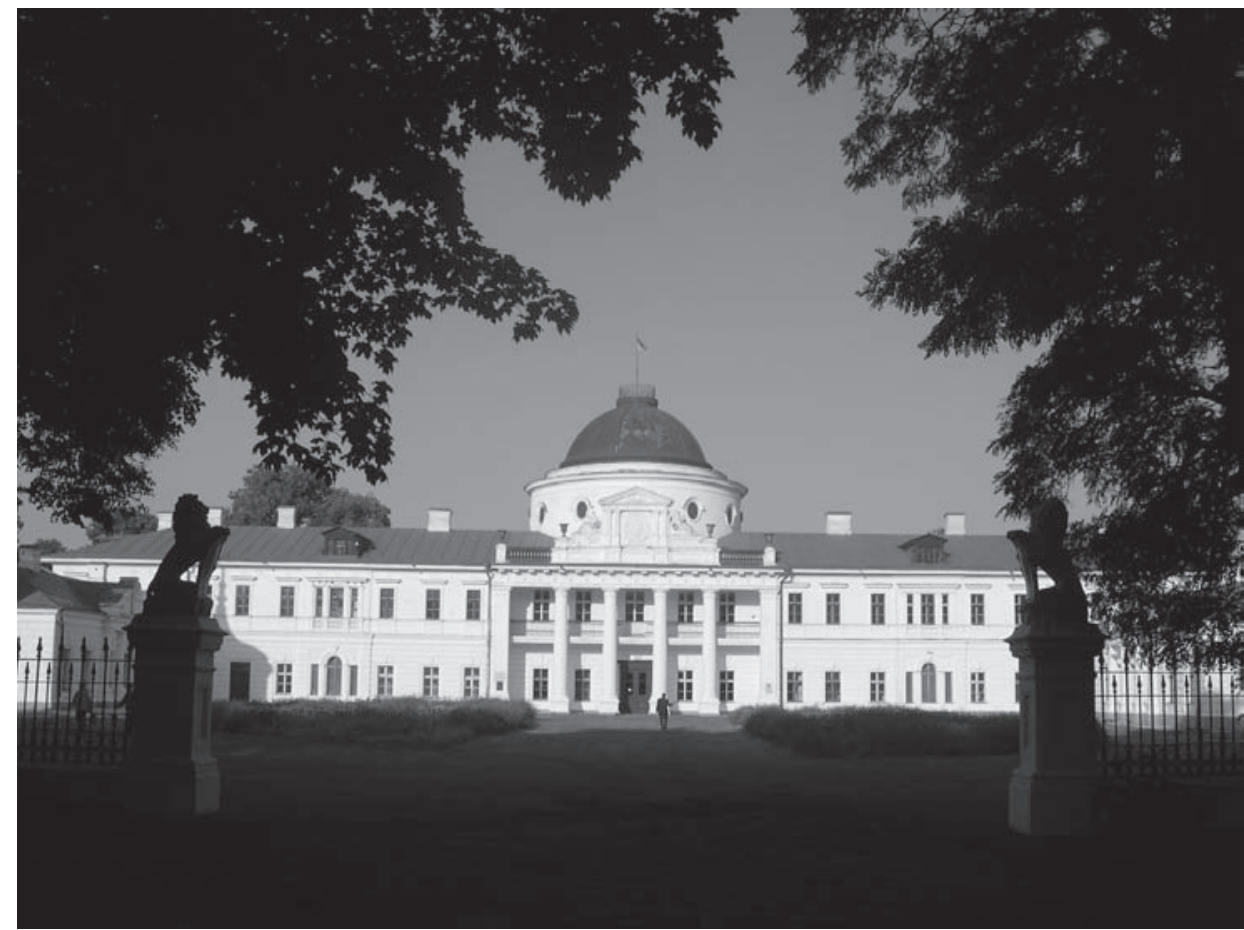

Fig. 1. Kachanivka palace (foto-O. Remeshylo-Rybchynska).

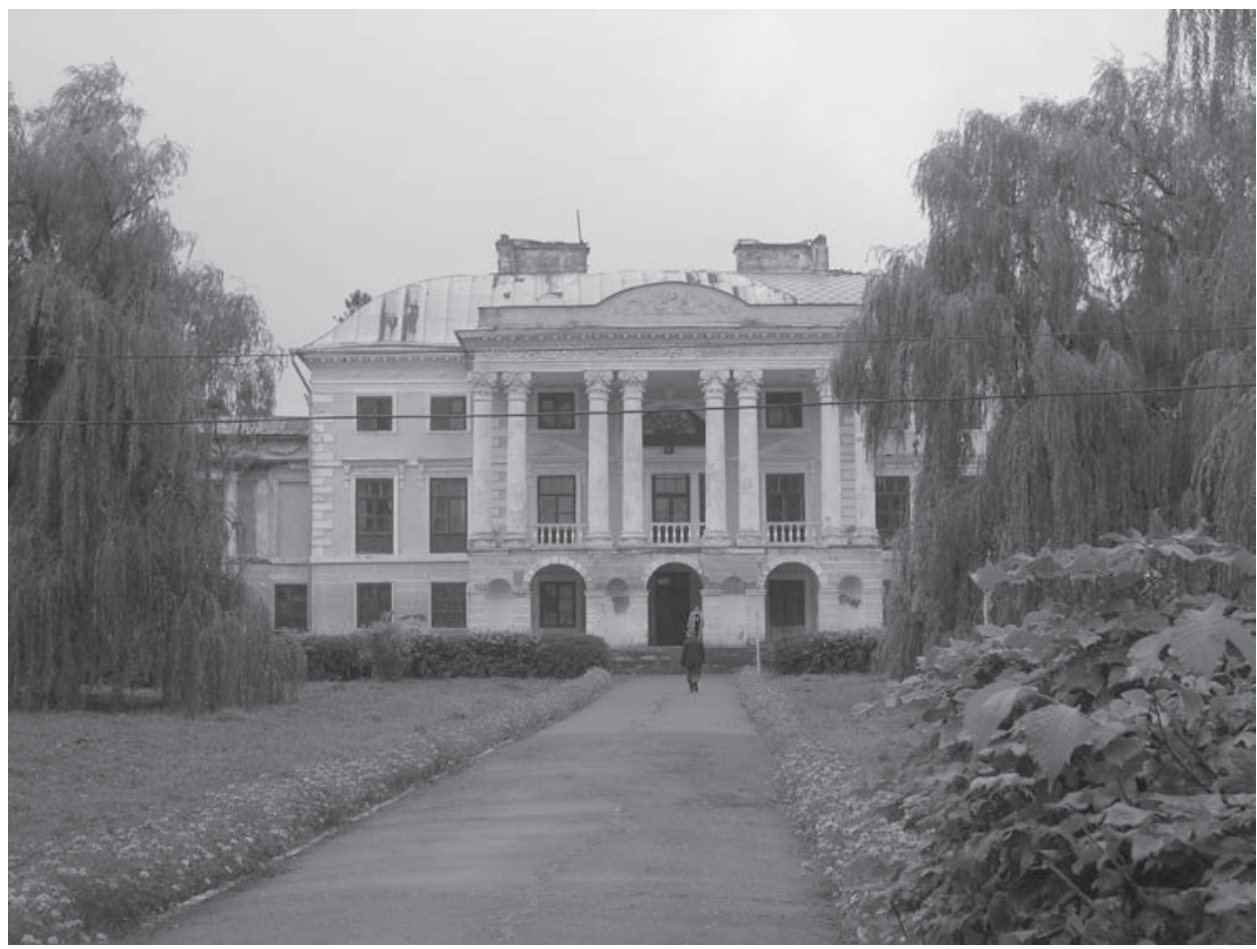

Fig. 2. Nemyriv Palace (foto-O. Remeshylo-Rybchynska). 


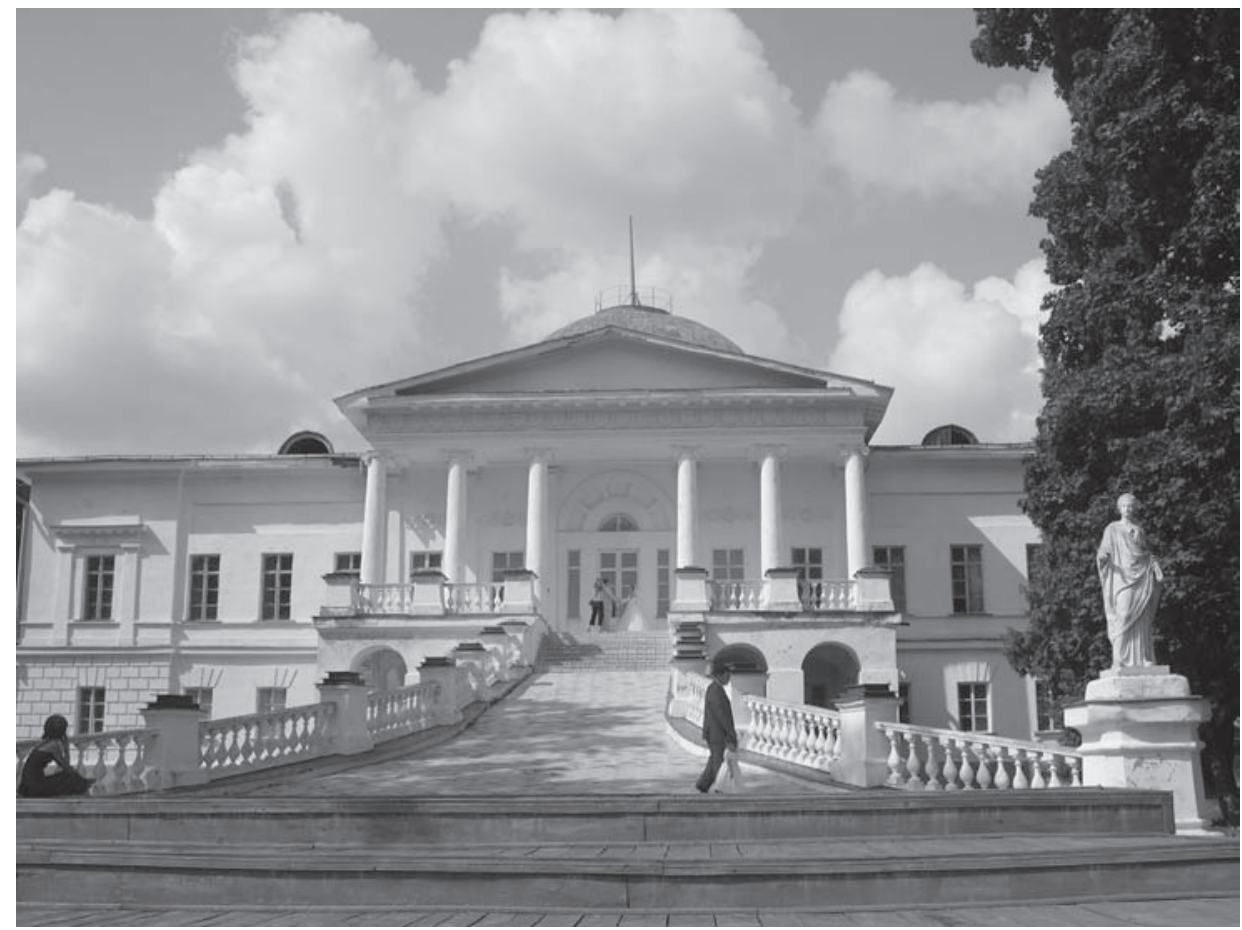

Fig. 3. Sorochynci palace (foto - O. Remeshylo-Rybchynska).

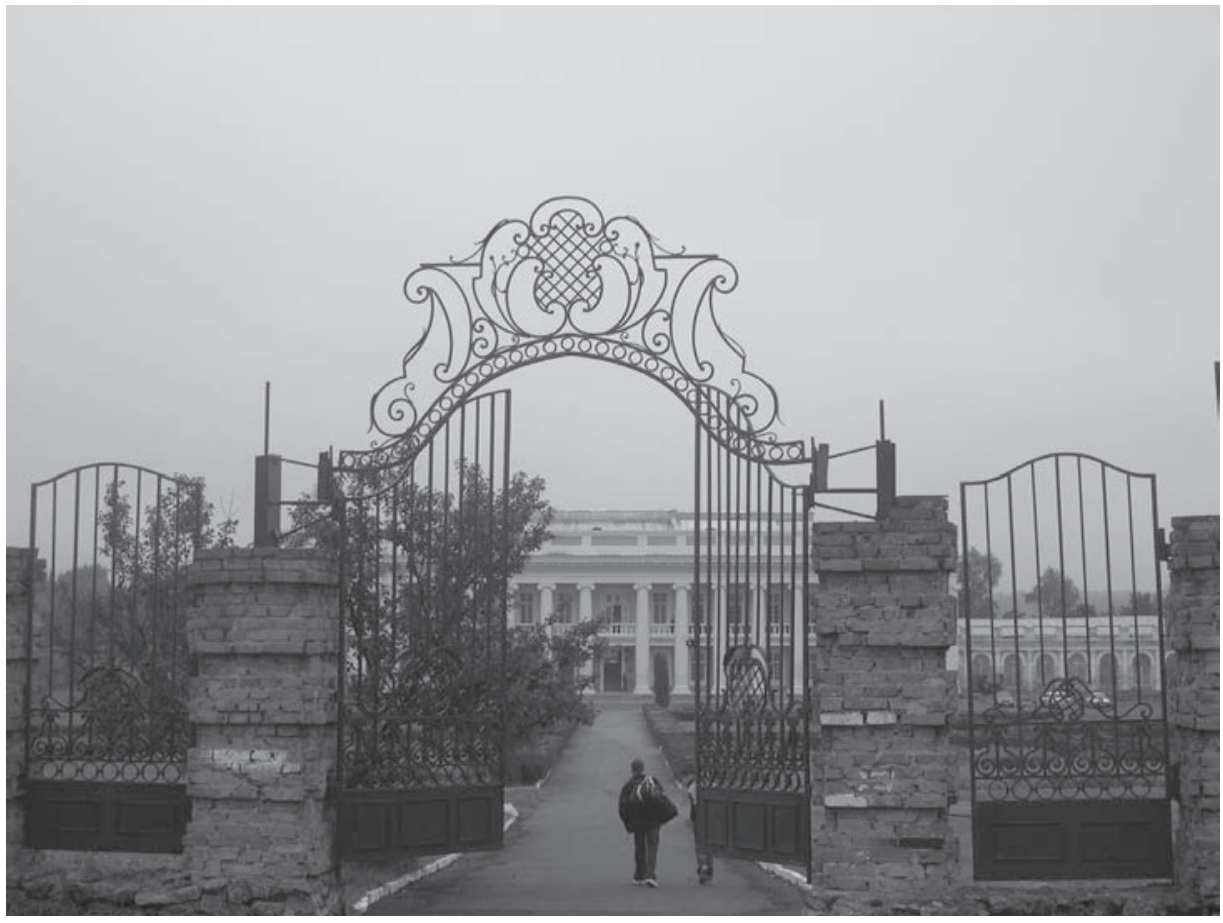

Fig. 4. Tulchyn palace (foto-O. Remeshylo-Rybchynska). 


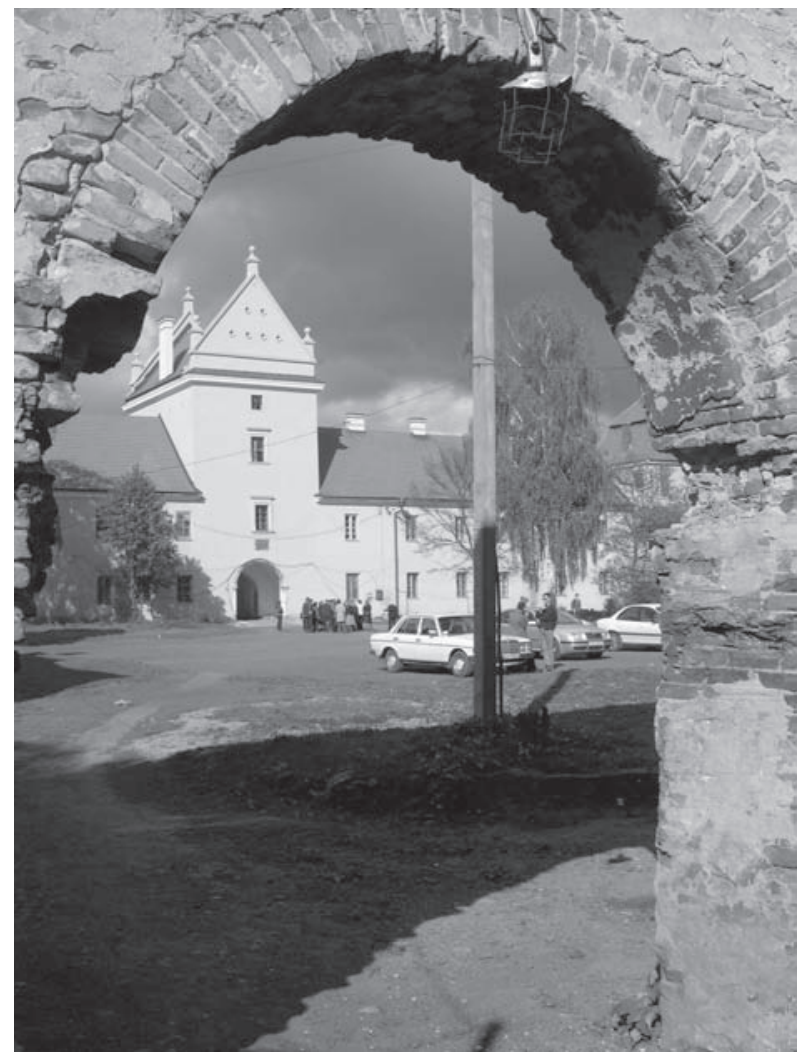

Fig. 5. The castle in Zovkva (foto - O. Remeshylo-Rybchynska).

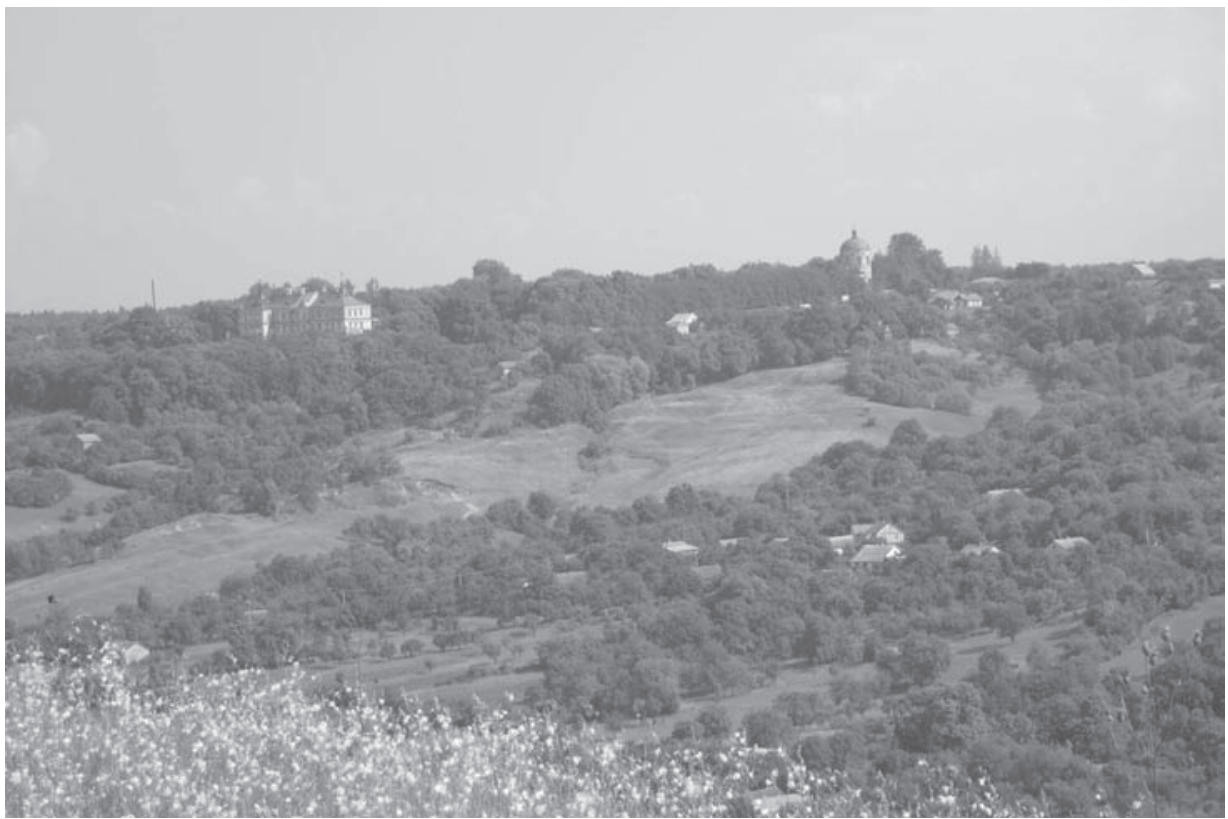

Fig. 6. Castle-park complex in Pidhirci (foto-O. Remeshylo-Rybchynska). 


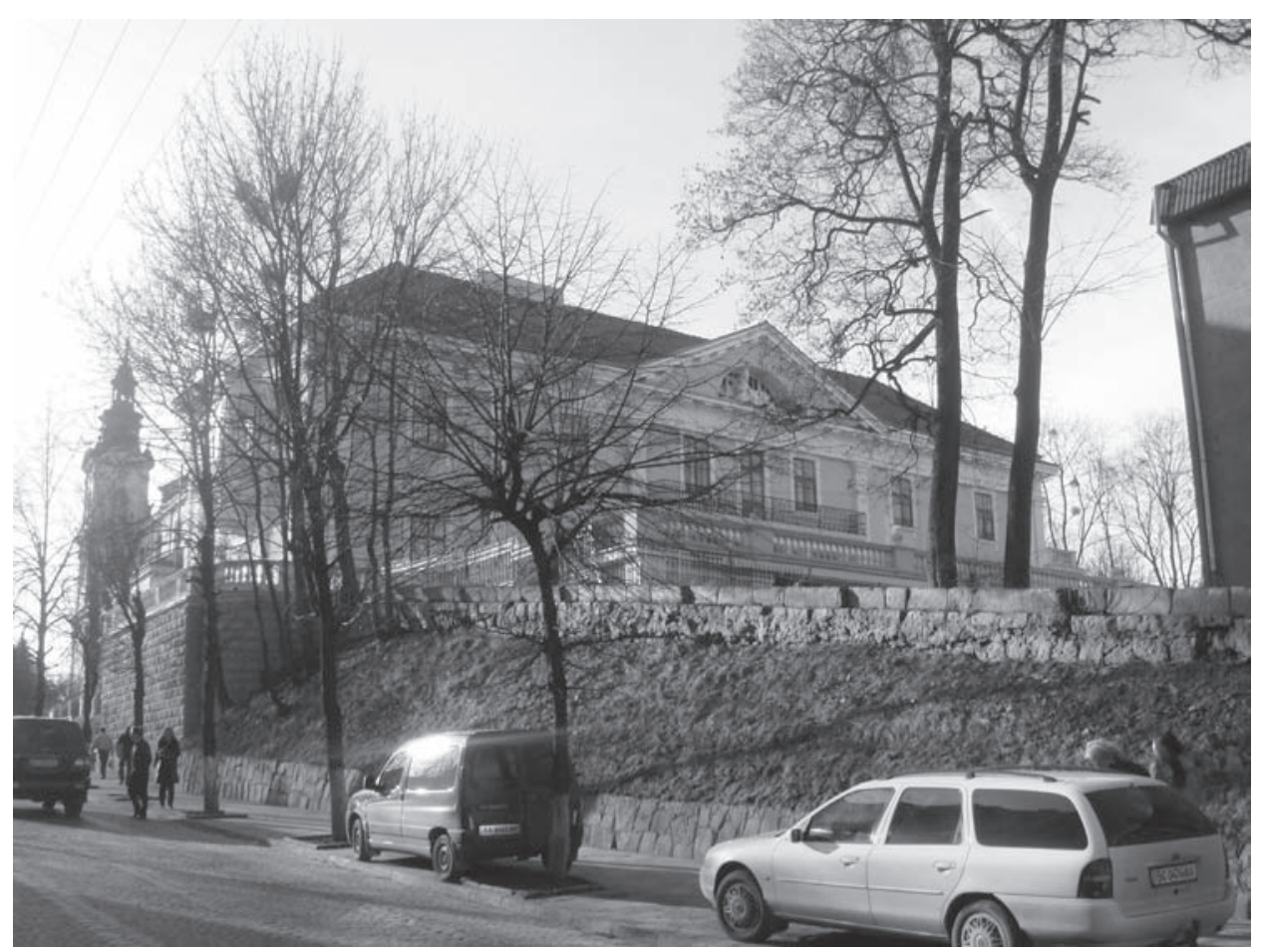

Fig. 7. Lviv, Seniavski palace (foto-O. Remeshylo-Rybchynska).

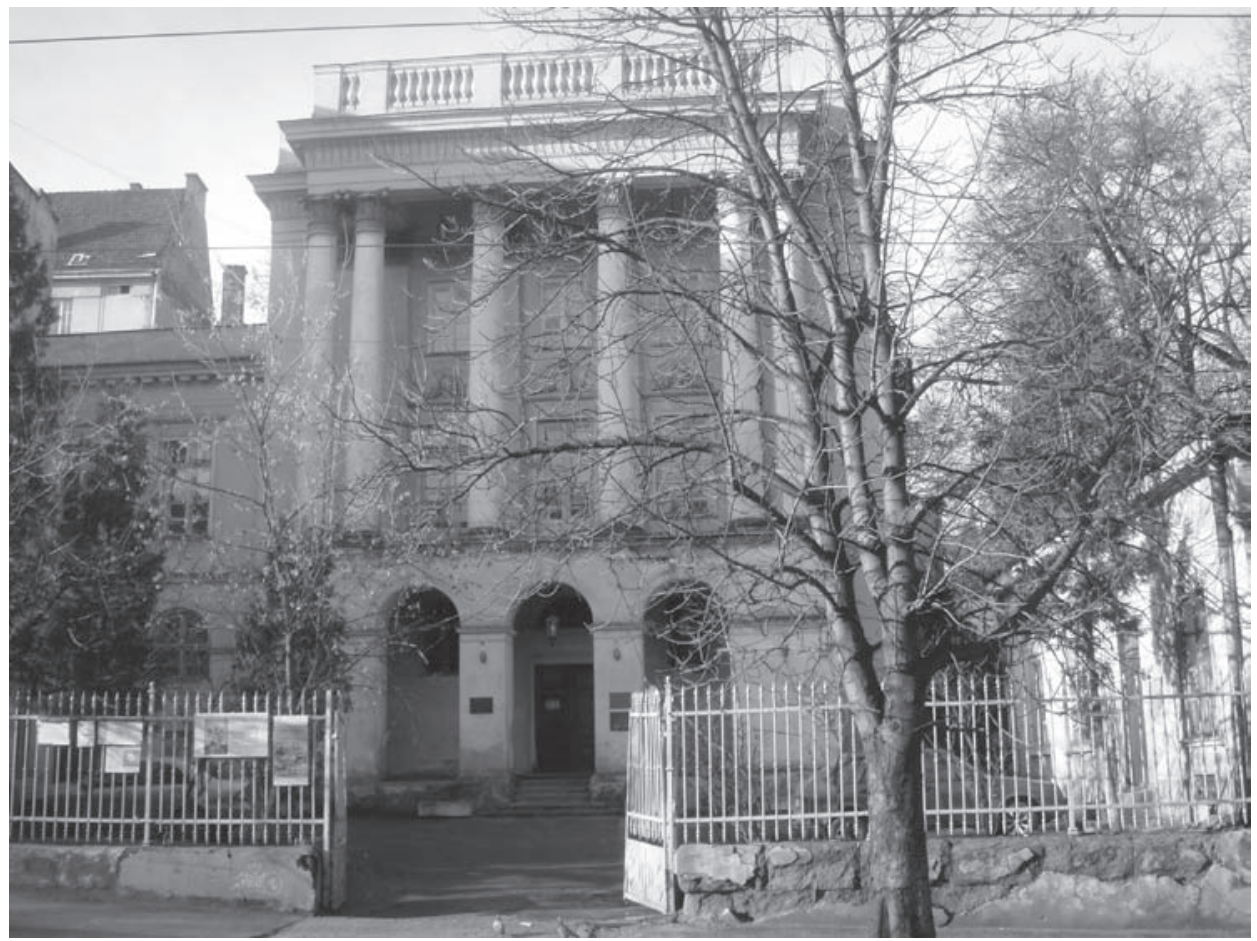

Fig. 8. Lviv, Palace of Belsky family (foto - O. Remeshylo-Rybchynska). 


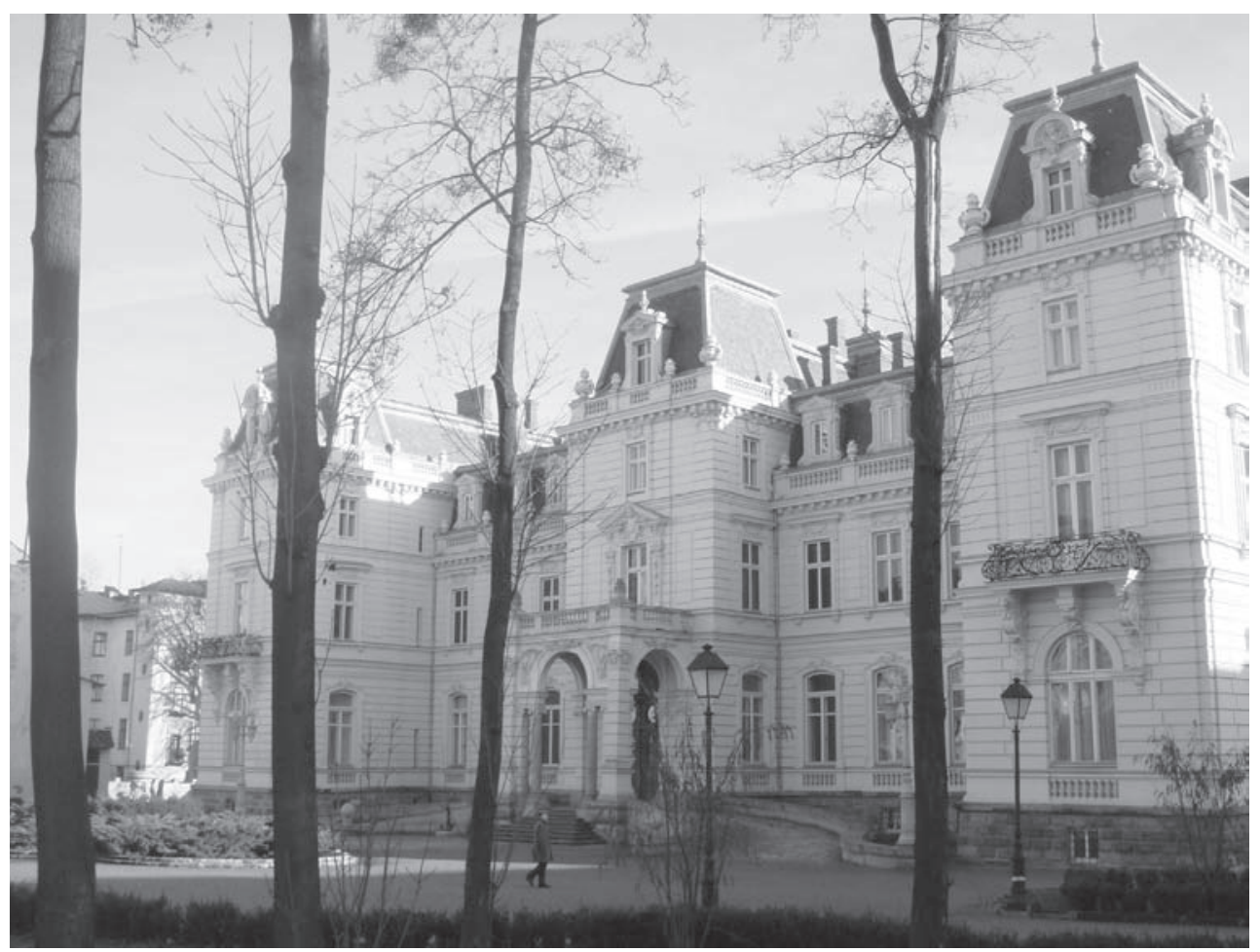

Fig. 9. Lviv, Potocky palace (foto-O. Remeshylo-Rybchynska).
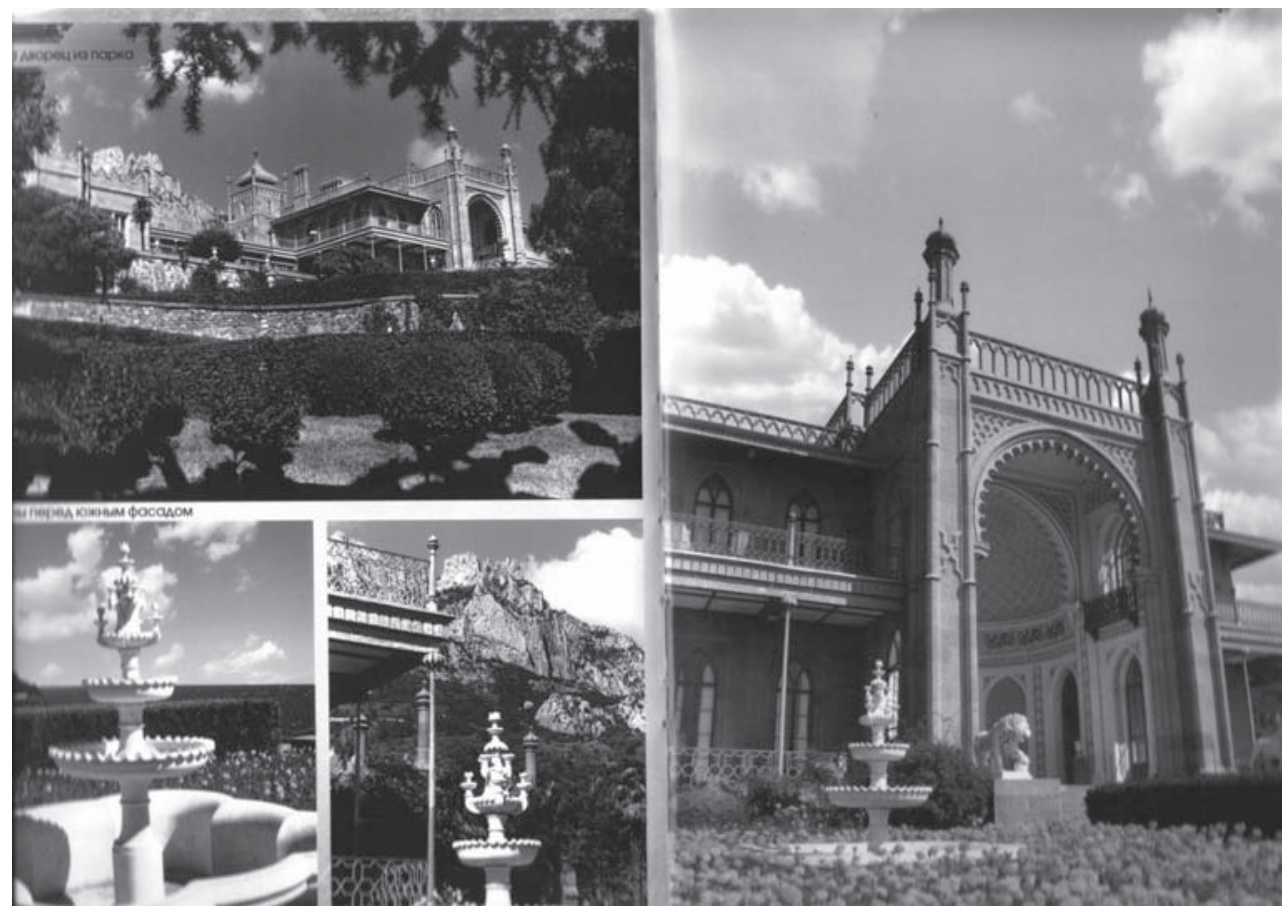

Fig. 10. ALUPKA, Voroncov Palace and Park Complex in Crimea. 


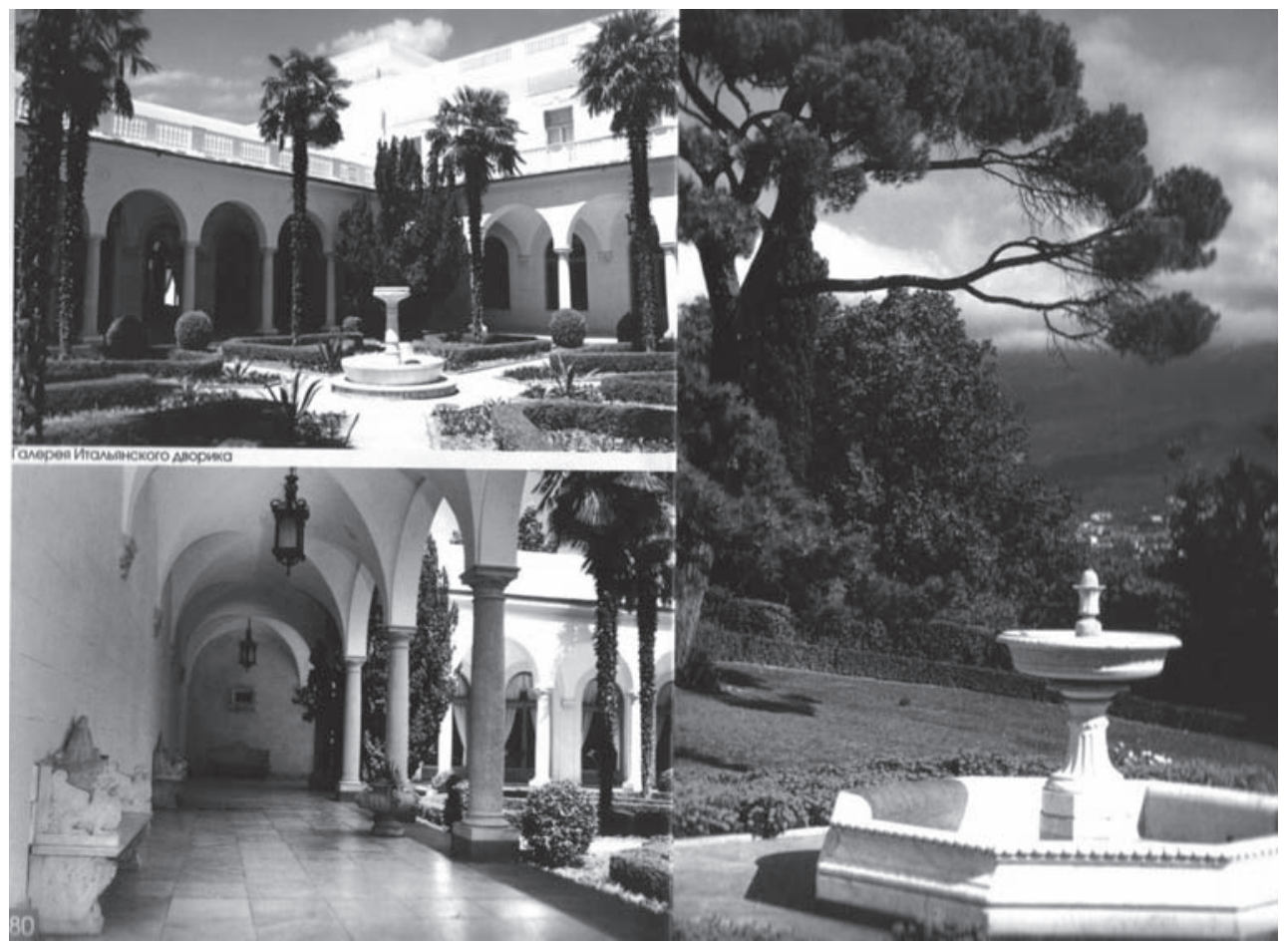

Fig. 11. Livadija Palace and Park Complex in Crimea.

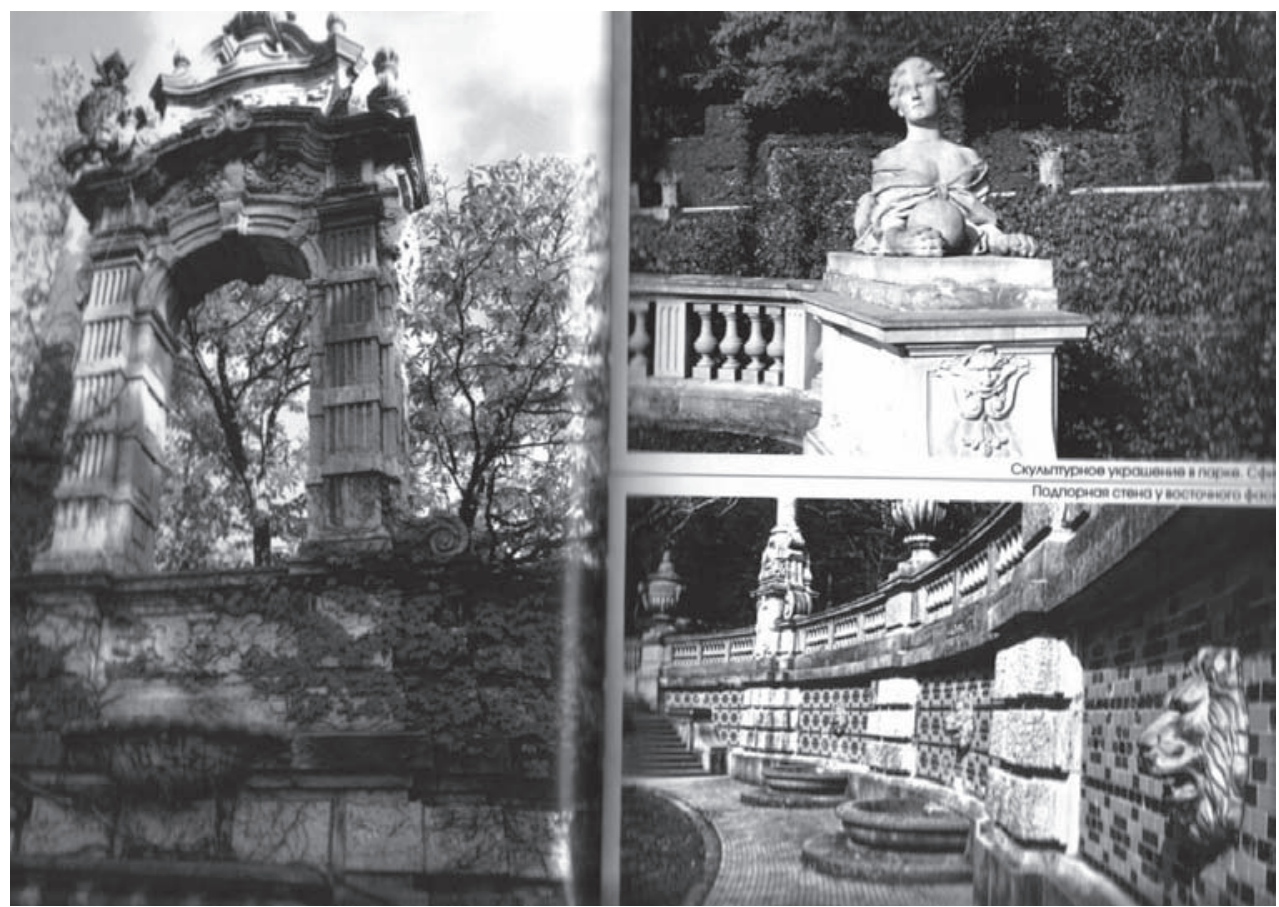

Fig. 12. Massandra Palace and Park Complex in Crimea. 
Historical palaces and gardens art, as a component of urban and natural reserve fond of Ukraine, are mostly located in Lviv, Chernivtsi, Cherkasy, Zhytomyr and Vinnytsia regions. Only in Kyiv and Crimea there are 9 parks-monuments of garden-park art of state value in each [10].

The status of Reserve have such all-known landmarks of garden-park art as "Sofiivka" in Uman, "Aleksandriya" in Bila Tserkva, "Trostianets" in Chernigiv region, "Veseli Bokovenky" in Kirovograd region and others [11].

The landmark of garden-park art "Sofiivka" has a documentation that points out its place in the system of biosphere forming processes in Ukraine. This dendrology park is also analyzed as a system that by it's location in central part of the state, nearby Kyiv, gives a significant economical effect.

For returning to objects of palaces and garden- art esthetical meaning and their functional fulfillment is necessary to use the term "Revalorization". By this term we mark exposing and reveal of historic-cultural value of park-garden art objects by restoration means and the way of maximal conservation of authentic material substance of spatial composition cultivation [13], [14].

On the primary stage monument of palace and garden art revalorization works is necessary to make a "Complex evaluation of the territory and planting". This analysis is supposed to be broken on stages. At first, the primary information accumulates, that reflects an existing condition and documentation available concerning the object explored. On the second stage the data is analytically worked out on the basis of fact groups and characteristics that are comprised with analogies later. The third stage gives a classification to parameters and characteristics on chapters: soils, relief, water system, plants, architectural structures, small shapes etc. On the fourth stage the specific of palace, park or garden is defined, work and purpose of the work planned, counting the stated-above classification and characteristics. Such material is represented in schemes, plans, tables, and text material, detailed pictures. All this together forms the basis for elaboration of the project and revalorization work methods.

The next phase includes sanitarian-curing chops and planting of trees and bushes, creating or renovating lawn covering, according to appropriate institution's agreement revalorization plans.

Further phases consist of restoration or reproduction of garden-park architecture objects and small shapes, paths building according to the vertical-planning scheme made, maintaining technologies, installing drainage.

It is necessary to hold on to principles of spatial-profoundness and volume composition building:

- location of general garden-park ensemble idea and developing the main motif, which overtakes plant compositions;

- opening or isolating relatively to surrounding landscape;

- creating in inner and outer scenery contrasts or harmony of green planting composition;

- gradual opening of spaces.

Therefore, in regard of above-stated action complex that seems like the term "revalorization" has proved its use in national monument-protection business and methods of its performing appropriate to international standards. 
Such action is taken, according to elaborated by author "Complex Program of residence, palace and garden art monument revalorization of XVII-XVIII century" on the territory of castle complex of Konietspolski, Sobieski, Zhevuski in Pidgirtsi, Lviv region.

Great work on revalorization of palace garden and parks of historical cities Lviv and Zhovkva is planned. There is an analysis of severe regime guardian ways planned there, performing actions on renovation and conservation of historical plant genders, saving view scenarios and panoramas, removing non-harmony objects. Grand revalorization works take place in Crimea also: ALUPKA, Voroncov Palace and Park Complex, Livadija Palace and Park Complex, Massandra Palace and Park Complex.

Developing of new vision for solving the revalorization of palace and gardens cultural landmarks of Ukraine is actual.

Important to notice that Florentine Harty on Protection of Historical gardens even 25 years ago (May 21, 1981) mentioned that like a living monument, historical garden needs special rules of protection! [15] Unfortunately, practically developing scientific-exploration and practical works on cultural heritage renovation, landmarks still stay beyond the line of primary work on their financing and performing. Very often it is hard for not competent bureaucrats to realize the complication of revalorization process and multiyear period of such heritage regeneration, developed as a result of epoque civilization processes of multinational cultures.

Monuments of garden-park art in Ukraine could be divided on certain categories, according to existing documentation and project-revalorization initiatives on modern level:

1 - partly damaged objects with complete maintenance of iconography, archive documents, existing project plans on their revalorization (most of the monument of XIX century);

2 - partly damaged objects with some maintenance of pre-project documentation (monuments of XVIII-XIX century);

3 - partly damaged objects with lost documentation of their primary image (monuments of XVII-XVIII century);

4 - lost objects, existence of certain iconography and archive materials (monuments of XVII-XIX century).

In the 3rd case, together with working out of parallel documentation (descriptions, memories), studying of cartography materials, exploration of artistic images from engravings and sketches - is necessary to take action in park archeology and disclosing of basic networks of plan scheme in historical gardens and parks. Such work first started in independent Ukraine with our initiative owing to collaboration with Lviv National Polytechnic University and Center of Exploration and Documentation of monuments in Warsaw - in upper mentioned Pidhirci castle complex in 2004. Collaboration was productive and has to be prolonged.

According to Paragraph 11 Law of Ukraine "About protection of cultural heritage", where is stated that “...institutions of science and culture, public organizations, citizens assist to organs of cultural heritage protection in work on protection of cultural heritage..." [16] could be overcame:

- Inertness of scientific-exploration and project institutions; 
- Irresponsibility and impunity of bureaucrats on state and local level;

- Uncoordinated work of state administrative, scientific, project and educational institutions.

One more way to overcome difficulties, such as: slowing down.

Process of projecting because of intensive state demand absence; particular realization of projects made; not comfortable condition for performing process of scientific-exploration elaboration, necessary for revalorization - in particular visa regulation with European Union countries, where there is a need to work in archives and libraries.

So, in such a way:

- Palaces, gardens and parks, as a part of significant historic-cultural heritage in Ukraine are subjects to state protection, represented in all state regions, own the grand esthetical potential - demand a lot of funding and effort from specialists for performing the complex work on their revalorization.

- One of the ways for ameliorating such work performance and it's financial guarantee is creation the Coordinate Center. In its business it will suppose to refer to the model of territory planning organization. On the regional level the assistance to these processes would be the general model construction on localization and spatial connections of main territory system elements.

- Probably at the beginning in terms of international collaboration it's necessary to talk about creating such a structure in western region of Ukraine, regarding Trans-boarder possibilities and existence of many parks and gardens.

- There is still an opened question of creating law mechanism on protection of cultural heritage on the basis of universal character international agreements. It would unify norms, which expect protection of cultural heritage on world scale. On national level it is important to finish with law basis on protection exactly monuments of garden-park art and to enlist funds on this need from private people and organizations.

- On the other hand defects of process forming in Ukraine the model of specialist architect - landscape projecting and restoration of garden-park art, could be removed by creating appropriate institution on further educating specialists after diploma on national and international levels, that states the document, accepted in Colombo 1993.

- Moreover, concerning high quality personal preparation and also for performing certain work on park and garden revalorization in terms of projecting or on objects directly,- it is necessary to elaborate international projects, draw the collaboration with international specialists, create common Programs, that would be invested from international funds. This would promote further integration processes on the way of forming recreation and tourism conditions in common European home.

\section{References}

[1] Akulenko V.I., Kulturna spadsyna ludstva. Zberezennia i vykorystania, Lviv, "Feniks", 2002, 160s., s.42.

[2] Zastavnyj F.D., Geografija Ukrajiny, Lviv, "Svit”, 1994, 471 s.; Mistobuduvannia. Dovidnyk proektuvalnyka, red.Panczenko T.F.,K,Ukrarchbudinform, 2001, 190s. 
[3] Nudelman V., Planuvalna organizacija terytoriji, Mistobuduvannia, K, Ukrarchbudinform, 2001, 188s., s.10-11.

[4] Bilokon Ju. Transkordonni regiony, tam ge s.16-17.

[5] Zi Zvernennia Dergavnoho sekretaria ministerstva kultury i mystectva Ukrainy V.L.Stasiuka. Miznarodnyj dosvid ohorony kulturnoji spadscyny ta pamiatkoohoronne zakonodavstvo Ukrainy, K.,"Stylos", 2002, 194s., s.7.

[6] Derzavna kulturna polityka: poniattia, zavdannhia ta pryncypy, Akulenko V.I. ta inshi Kulturna spadscyna liudstva. Zberezennia ta vykorystannia, Lviv, Feniks, 2002, 160s., s.43-44.

[7] Kapustian V.V., Parky: mynule, sucasnyj stan i problemy rekonstrukciji, Poezija ukrajinskoho sadu,"Hronika-2000", K, 2001,796s., s.7.

[8] Bodnar Ju. Kompleksna zelena zona, Mistobuduvannia, s.73.

[9] Pancenko T., Somonova O., Pryrodno-zapovidni terytoriji, Mistobuduvannia, 98-99.

[10] Zastavnyj, s.104.

[11] Rodickin I., Sadovo-parkovoje iskustvo Ukrainy-sostojanije, problemy, perspektivy, Hortus Vitae. Jsrodek Ochrony zabytkowego Krajobrazu narodowa instytucja Kultury, Warszawa 2001, 334s., s.205-213.

[12] Bodnar Ju., Parky, sady, skvery, bulvary, Mistobuduvannia, s.81.

[13] Pribieha L., Do pytannia terminologicnyh vyznacenu sferi ohorony istorycnyh mistobudivnyh utvoren, Problemy reheneraciji istoryko-arhitekturnoho seredovysca: Materialy naukovo-praktycnoji konferenciji, K.,1994, s.3-4.

[14] Bevz M., Metodolohicni osnovy zberezennia ta reheneraciji zapovidnyh arhitekturnyh kompleksiv istorycnyh mist na prykladi Zahidnoji Ukrajiny), Avtoreferat dysertaciji na zdobuttia naukovoho stupania doktora arhitektury. Harkiv, 2004, 32s.

[15] Miznarodna Hartija $z$ ohorony istorycnyh sadiv (Florentijska hartija. 1981r.), Ohorona kulturnoji spadscyny, K., "Artek", 2002, 135s., s. 72-74.

[16] Zakon Ukrajiny "Pro ohoronu kulturnoji spadscyny", K., Parlam. v-vo, 2005., 40s., s.17-18. 